\title{
Predicting the Financial Failures of Manufacturing Companies Trading in the Borsa Istanbul (2007-2019)
}

\author{
Hasan Demirhan1 (1), Güven Sayilgan² \\ ${ }^{1}$ Black Sea Trade and Development Bank, Thessaloniki, Greece \\ ${ }^{2}$ Ankara Üniversitesi, Ankara, Turkey \\ Email: hdemirhan1@yahoo.com
}

How to cite this paper: Demirhan, H., \& Sayilgan, G. (2021). Predicting the Financial Failures of Manufacturing Companies Trading in the Borsa Istanbul (2007-2019). Journal of Financial Risk Management, 10, 416-452.

https://doi.org/10.4236/jfrm.2021.104023

Received: September 4, 2021

Accepted: October 26, 2021

Published: October 29, 2021

Copyright $\odot 2021$ by author(s) and Scientific Research Publishing Inc. This work is licensed under the Creative Commons Attribution International License (CC BY 4.0).

http://creativecommons.org/licenses/by/4.0/

\begin{abstract}
This study aims to develop financial failure prediction (FFP) models by utilizing the firm-specific financial ratios and variables related to the stock market and macroeconomic indicators for Turkish manufacturing corporations, which traded stocks on the Borsa Istanbul between 2007 and 2019. The statistical methodology utilizes binary logit analysis to construct FFP models for less restrictive assumptions and the most relevant independent variables every three years before the financial failure. Model scores are built for the sector groups: "Production and Manufacturing", "Trade and Transportation", and "IT and Administrative Services". Companies data are further divided into two subsets for each sector: training (60\% samples) and test models (40\%). After the factor analysis exercise performed at the initial stage, liquidity, leverage, and profitability ratios are found to be the important financial factors in the model predictions. Besides, macroeconomic and stock market variables such as non-performing loans-to-total loans ratio, loan interest rates, and BIST industrial index are also observed to be critical factors in the financial failure prediction model. In the next stage and subsequent to the application of the stepwise logistic method, the reduced financial ratios regarding the leverage and profitability along with only the Borsa Istanbul industrial index are observed as the most effective contributive variables in predicting an accurate model before one, two, and three-year prior to the financial failure in across the three sub-sectors. The test sample's predictive power strongly validates the high classification results obtained from the trained model within each sub-sector.
\end{abstract}

\section{Keywords}

Financial Distress, Financial Failure Prediction (FFP), Financial Ratios, Logit 
Regression, Market and Macroeconomic Variables

\section{Introduction}

Predictive models forecasting companies' financial failures have garnered significant attention from researchers owing to the critical insights they can offer. Financial failure prediction (FFP) models play a vital role in mitigating high risks to stakeholders and the national economy.

Financial failure is a broad term, which refers to a company's inability to fulfill its financial obligations. A company is contractually bound by its stakeholders (financial institutions, tax administration, employees, shareholders, etc.) in a given and predetermined time and amount. Financial failure stems from internal factors, such as monetary, business, and operational risks, leading to insufficient revenue and liquidity to cover expenses and service debt. Consequently, a company is forced to cease its operations. However, such internal (firm-specific) risk factors can be controlled if the management takes necessary measurements on time.

Various other external or macroeconomic factors, called systematic risks, can also cause companies' financial failure. Major external factors such as growth rate, national/global financial crisis, inflation, rapid increase in interest rates, quick exchange rate movements, sharp changes in national monetary policies, global social and health (pandemic) issues pose a potential risk. Systematic risk is broader and more uncontrollable than internal factors; thus, management measures cannot easily mitigate it.

In today's business climate, increasing globalization and international value chains in global markets based on fast-changing digital computing technologies have forced companies to face intense competition in all sectors. Additionally, in global financial crisis cycles, pandemics and other regional calamities have caused negative economic growth, a rapid increase in the unemployment rate, the volatility of commodity prices, non-performing loans' spikes, bankruptcies, and economic contractions that increase financial difficulties and uncertainties for businesses. These various forms of crises can be observed worldwide with varying severity levels depending on the countries' developmental levels and crisis monitoring capacities. For example, Turkey is the only country that experienced a financial crisis in 2001-2002. In 2008 the global economy witnessed a severe financial crisis. The impacts of this economic downturn only fully manifested in the Turkish economy in 2012 and 2013. Despite the normality in the global economies, Turkey began to face an economic crisis at the end of 2018. The full scale of its impact unfolded in the subsequent 2 - 3 years, parallel to the global pandemic outbreak in 2020 .

Accordingly, the burden of a business failure rests not only on the immediate stakeholders of a company but also on the relevant industry and national econ- 
omy. Therefore, developing and implementing financial failure models is critical to the relevant stakeholders to control the damage. In this regard, the lenders can use the models as "early warning systems" to reduce non-performing loan risks. Many central banks and regulatory supervision authorities have been developing a prediction model as an effective early warning system for both banks and companies (Davis and Karim, 2008). In addition, governments continuously encourage companies and financial institutions to establish effective detection models to reduce the likelihood of failure and minimize costs to the economy. In short, using a successful FFP model can be instrumental in providing significant benefits to a wide range of individuals and institutions and their respective stakeholders to ensure healthy economic decisions and preventive action at an early stage.

\subsection{Business Failures}

Financial difficulties or distress commonly encountered in the financial literature are scenarios of financial failure, economic failure, technical failure, negative net worth, and bankruptcy. Financial failure and other concepts of failures, such as economic and technical failure, need to be addressed to identify types of risks that require unique measures. Economic failure, in particular, is reflected when a company's profitability is below the cost of equity over a successive number of years. In other words, company costs are higher than the average cost of the sector in which it operates. Economic failure results from incompetent management of the company's activities.

Conversely, technical failure results when a company cannot fulfill its current liabilities owing to unsuccessful cash management, despite its total assets covering total debts. In other words, the problem lies in the timing mismatch of cash flows aligned with inefficiency in optimizing and managing the liquid resources, more specifically, the working capital. As such, insufficient coverage for current liabilities because of a shortage of current assets exposes companies to technical failures. Technical failure can be sorted out within a reasonably short period when rapid action is taken. Otherwise, the business reaches a turning point where it falls into financial failure (Ertan and Ersan, 2018).

A company earns the legal status of bankruptcy by the court following a legal process initiated by the unpaid creditor or creditors. Creditors present a petition to the court that the company cannot pay its due debts, and the court accordingly declares the company insolvent (Sun et al., 2014).

Researchers differ in defining financial difficulties as a failure criterion in their studies. For example, Beaver (1966) defined financial difficulty as the company's inability to pay interest on a debt. Altman (1968), Deakin (1972), Ohlson (1980), Zmijewski (1984) considered the bankruptcy status of a company in their analysis. Blum (1974) defined financial difficulties as the company's failure to pay its due debts. Taffler (1983) considered the stage where creditors applied to the court for a failure criterion. 
The relevant literature shows a paradigm shift away from the classic legal definition such as bankruptcy to a more extensive definition of financial failure that includes economic failure, technical failure, and bankruptcy.

\subsection{Objectives of the Study}

The objectives of this research targeted to achieve the following results:

1) To develop and test FFP models by utilizing the firm-specific financial ratios and variables related to the stock market as well as macroeconomic indicators for Turkish manufacturing corporations, which traded stocks on Borsa Istanbul (BIST) from 2007 to 2019. The three sets of variables and binary logistic regression analysis, which adapted the outcome of "failed" or "not failed" classification, are used to determine indicators of financial failures and improve the accuracy of the model predictions.

2) To measure and test the predictive power of selected explanatory variables and evaluate their predictive accuracy rates up to 3 years before the failure date.

3) To provide tools used in the risk assessment process as an early warning system by the relevant stakeholders (lending institutions, investors, shareholders, relevant public institutions, audit and rating institutions). These stakeholders will then take timely preventive measures against corporate financial failures.

4) Finally, to help reduce or eliminate the financial losses for shareholders (capital providers) and financial institutions.

The paper is structured as follows: Section two presents the literature review, a relevant overview, and discusses FFP models using various modeling methods and procedures in the corporate finance area. Section three covers the data treatment and preparation (cleaning and structuring) with the required techniques for further statistical analysis. Section four is devoted to developing various predictive models for financial failures, identifying significant predictors in the models. The importance of explanatory variables' is assessed and compared with different FFP models estimated for each sub-sector group. Finally, the last section summarizes the findings.

\section{Literature Review}

Academia has witnessed a surge in research on FFP models in the corporate finance area using various modeling methods and procedures, each with assumptions and computational estimation techniques. The purpose is to develop the most optimal performance prediction model for classifying companies according to their financial soundness.

The salient issue is resting at the height of financial failures in developing successful prediction models (early warning systems) that can alert financial stress and rank companies in terms of suitability for external/governmental support. This section briefly reviews changes observed in the use of variables (from single to multivariate analysis) and the methods (from classical statistical methods to artificial intelligence-driven models) in the literature regarding fi- 
nancial prediction.

\subsection{Estimation Methods}

The literature tackles different estimation methods used in evaluating and predicting companies' failure risk. Historically, as cited in the study of Uğurlu and Aksoy (2006), researchers such as Ramser and Foster (1931), Fitzpatrick (1932), Smith and Winakor (1935), and Merwin (1942) analyzed financial ratios using the comparative quantitative method and reached meaningful results without using statistical methods.

In the 1960s, Beaver (1966) was the first researcher to use a single statistical technique variable (univariate analysis) in his financial failure study. He researched 79 successful businesses and 79 unsuccessful businesses from 1954 to 1964. The author tested one financial ratio out of thirty financial ratios each time on a rotational basis. He concluded that six financial ratios (independent variables) were more relevant to construct univariate discriminant models. Out of six, the best financial ratio was the "cash flow to total debt ratio" with a $10 \%$ misclassification rate over five years up to the failure.

Following Beaver's (1966) statistical technique, advanced statistical methods have been developed using computers in this field. Thus, the univariate analysis is no longer used for the prediction models. Currently, conditional probability models, mainly logistic (logit), probit, and linear regression models, are commonly used in corporate failure predictions.

Altman (1968) is one of the pioneers of multivariate statistical models in predicting financial failure. He developed a better estimation model with financial ratios using the multiple discriminant technique in his research. Using a matched sample, he examined 33 successful and 33 unsuccessful enterprises from 1946 to 1965. The author concentrated on the business size equivalence of the companies included in the selection. Companies that have gone bankrupt under the provisions of the American Bankruptcy Act were selected for discriminant analysis. A total of 22 financial ratios were chosen under five financial ratio groups. Among these, five financial ratios with the most predictive power were selected, and the " $\mathrm{Z}$ model" was developed according to Altman's definition. The five ratios that best distinguished successful/unsuccessful businesses were 1) total assets/networking capital, 2) retained earnings/total assets, 3) profit before interest and tax/total assets, 4) market value/total assets, and 5) sales/total assets. Altman (1968) tested his model for each of the five years before the companies' bankruptcy. The Z-Score model's predictive power with $95 \%$ was better at predicting a failing company one year before its failure than two, three, four, and five years before its failure. After the Z-Score model, Altman et al. (1977) developed a new ZETA model using statistical discriminant techniques. The ZETA model's predictive power in classifying insolvent companies was found to be more effective than the Z-Score.

Similarly, there are many studies using discriminant analysis that contribute 
to the literature. Libby (1975) and Deakin (1972) tested the same fourteen financial ratios, but only five financial ratios with the highest predictive power were selected as the independent variable for bankruptcy forecasting. The profitability ratio had the most significant predictive power among the five selected ratios.

Scott (1981) calculated the ZETA values using the multiple discriminant analysis and concluded that the ZETA model is the most discriminatory multidimensional method for classifying successful and unsuccessful firms. The author also concluded that the ZETA value is the most reliable since it gives the lowest classification error. His study used stock market data and generally accepted financial ratios as explanatory variables in the multiple discriminant analysis. More than thirty financial institutions used a model developed with the same independent variables in their credit risk assessment exercises.

Ohlson (1980) was one of the leading researchers who developed logistic regression models to predict financial failure. He was critical of the multiple discriminant analysis restrictive assumptions and the estimated results depending on these assumptions. Using the logistic cumulative distribution function and considering nonlinear factors, Ohlson estimated the parameters' coefficients by applying the maximum likelihood estimation method for the maximum failure prediction accuracy. A total of 105 unsuccessful and 2058 successful firms were included in the sampling cluster between 1970 and 1976. Generally accepted financial ratios in the literature were selected as independent variables. Ohlson (1980) developed three "O-Score models" by using the first O-Score model to represent the prediction one year before the company's financial failure. The rest followed the same suit until three years before the failure. The "first O-Score model" had the highest failure prediction accuracy with $96.12 \%$. Ohlson was one of the pioneers in developing the logit method as a new statistical technique for predicting the probability of financial failure. He observed that the logit regression method provides comparatively high accuracy in predicting financial distress subject to data quality availability.

Odom and Sharda (1990) developed a prediction model using five financial ratios of 65 bankrupt and 64 non-bankrupt firms based on the data covering the years between 1975 and 1982 in the United States. They made a comparative analysis on the results obtained from deploying multiple discriminants and artificial neural network methods. The test outcome revealed that the artificial neural network method provided more positive results in predicting the financial failure model than the multiple discriminant analysis.

Laitinen and Kankaanpaa (1999) conducted a comparative analysis on the success of prediction methods in their study in Finland. They compared six alternative methods: linear discriminant analysis, logit analysis, recursive partitioning, survival analysis, neural networks, and human information processing that are applied to FFP models. There was no statistically significant difference among the six methods used in estimating FFP within two and three years before the failure. 
After the 2000s, the discriminant analysis used in the FFP models has been gradually replaced by artificial intelligence (AI) systems and statistical techniques such as conditional probability models (CPM) like logistic (logit), probit, and linear regression models. AI has been used for multivariate regression analysis in predicting financial failures in parallel with software and computer technology developments since the 1990s. It can be programmed to learn how to estimate the parameters' coefficient and predict financial distress iteratively. For example, an artificial neural network (ANN) is a form of AI application using artificial neuron model predictions.

In the study conducted by Hall \& Pellet (2003), ANN was designed to measure the prediction accuracy for 38 distressed companies selected between 1975 and 1982. Thirty-three companies were successfully classified, representing $87 \%$ classification accuracy. Hall \& Pellet (2003) repeated their study using the statistical discriminate method and obtained an 85\% classification accuracy with the same data. Hence, ANN usage in measuring the prediction accuracy is marginally more successful than a discriminant method for classification accuracy.

Similarly, Dwyer (1992) predicted a financial failure model by deploying discriminant, logit, and ANN methods utilizing data for the period 1979-1986. Based on the results obtained, Dwyer concluded that logit models and ANN had the most accurate classification determinants compared with the discriminant method. When a further comparison is made, the ANN method's 78.9\% classification accuracy was reasonably higher than $76.3 \%$ of the logistic method. Therefore, Dwyer (1992) suggested that ANNs are the most reliable methodology for estimating failure prediction models.

Shi and Li (2019) conducted a literature review of the most commonly used methods such as ANN and CPM for bankruptcy predictions from 1968 to 2017. They observed that the deployment of ANN-based machine learning methods has been on the rise in this field because of rapid software technology enhancement. The author's analysis determined that 123 (51\%) scientific publications out of 240 utilized logit regression models within the CPMs. In the AI group's case, 56 (51\%) scientific publications out of 201 used the ANN in developing financial distress models.

\subsection{Research Studies on Systematic Risk Factors}

Most academic studies on financial distress predictions focus on financial ratios derived from firm-specific accounting data, which are microeconomic factors. However, after the global economic and financial crises in 1987 and 2008, studies using systematic risk factors (SRF) as independent variables in estimation models have increased rapidly. SRFs cannot be mitigated because they are outside the control of the company management. Such SRFs include but are not limited to changes in interest rates, economic crises, pandemic viruses, wars, the economy's growth rate, inflation, high-interest rates, fluctuations in exchange rates, and tight monetary policies (Korol and Korodi, 2010). 
Liu (2004) found a significant relationship between companies' failure rates and macroeconomic factors. The error correction model (ECM), a multiple-time series model based on quarterly data for 1966-1999 in the UK, was used in the calculation. Nominal interest rates, real profit rates, real loan amounts, and the general price index were used as independent macroeconomic variables. Among the macroeconomic variables, it was observed that the nominal interest rates were the critical factor in the companies' financial distress. Hence, it was recommended that authorities reduce companies' failure rates by changing interest rates as part of their monetary policy.

Christidis and Gregory (2010) in the UK included financial ratios (accounting-based) and macroeconomic indications as explanatory variables for the financial failure estimation using the dynamic logit model. The analysis consisted of 589 bankrupted and 49,063 successful companies registered on the London Stock Exchange between 1978 and 2006. Accounting-based data have a high contribution to bankruptcy prediction power, while market and macroeconomic variables make a moderate contribution to the model's prediction power.

Tinoco and Wilson (2013) performed the most comprehensive study, which included 23,218 observations on the financial ratios of 3020 publicly traded companies in the London Stock Exchange between 1980 and 2011 and the market and macroeconomic variables in the financial failure model. The variables used in this research were as follows: 1) financial ratios comprising performance measurement ratio (total cash input to total liabilities), debt ratio (total debt-to-total assets), total cash and cash equivalents to daily operating expenses, as well as total earnings (EBITDA $)^{1}$; 2) macroeconomic variables including inflation rate (consumer price index), short-term interest rate (3-month Treasury debt interest rate), an annual economic growth rate, and 3) market variables such as the market price of the stock, the annual cumulative return of the stock with monthly yield changes, the market capitalization of the company, and the company's market value to its total debt. Tinoco and Wilson's (2013) study on ANN used Altman's (1968) original Z-Score method and logistic regression analysis and compared the results. The variables used in all prediction models revealed mostly correct classifications and high predictive power of the financial distress model for up to two years before the failure.

Furthermore, Stenbäck (2013) developed a financial failure model including financial ratios and macroeconomic variables into the regression analysis. The data used in the model were collected from 200,000 observations of 35,000 construction and retail companies operating in Finland between 1999 and 2011. Financial failure estimation was calculated together with the companies' credit risk classification by deploying the logit regression method. Accounting variables consisted of profitability, borrowing (leverage), and liquidity ratios. Macroeconomic variables were construction and consumption industry indices, total national income, and consumer confidence indices. It was observed that macroe${ }^{1}$ Earnings before Interest, Taxes, Depreciation, and Amortization (EBITDA). 
conomic variables and financial ratios have a significant and explanatory effect on financial failures only during the 2008 financial crisis. However, firm-specific (financial ratios) variables seem to have better predictive power in estimating the financial default in normal circumstances.

Nouri and Soltani (2016) created a bankruptcy prediction model based on the data of 103 companies between 2007 and 2012, 53 of which were bankrupt and 50 successful. These companies were trading on the Cyprus Stock Exchange. These authors developed a bankruptcy prediction model with a logistic regression method by combining accounting, market, and macroeconomic variables. The estimation results were surprising, contrary to the expectations in the case of macroeconomic variables' impact. While financial and market variables revealed a high predictive power of $91 \%$ and $82 \%$ at one and two years before the companies' bankruptcy, macroeconomic variables did not contribute to the model's prediction power in the same periods.

Pham Vo Ninh et al. (2018) created prediction models based on 6,735 observations of 800 companies and a large sample size covering 2003-2016 in Vietnam. Similar to the earlier models, the bankruptcy prediction model was developed using accounting (rates), market, and macroeconomic variables. The coefficients' estimates were made using mainly Altman Z-Score and Merton statistical models. Each group of variables (accounting-financial ratios, market, and macroeconomic) was calculated separately to estimate the predictions. There was a meaningful and explanatory relationship between each group variable and financial failure. However, when all groups' variables were calculated, only accounting ratios were significantly more substantial than those in the model prediction.

In Turkey, Ertan and Ersan researched in December 2018 using the systematic risk variables to calculate the factors determining financial failure in the manufacturing sector. Semi-parametric (Cox proportional risks), parametric (panel probit, panel logit, complementary log-log, log-logistic) survival, and panel random methods were used as estimation methods. It was observed that Cox proportional hazards are the most successful method, and log-logistic is the next one in predicting the financial failures. According to the research findings, an increase in firm-specific factors such as cash ratio, shareholders' equity, capital turnover rate, and net foreign exchange position decreased the risk of financial failures. Conversely, a decrease in other firm-specific factors such as current ratio and profit ratios increased the risk of financial failures. It was also found that firm age and good corporate governance, as well as the ease of doing business ranking and the dummy variable regarding the influence of global financial crisis, are critical, independent variables in explaining the risk of financial failures.

\subsection{Research Studies on Turkish Companies}

Erkut's (1981) seminal work on FFP is considered an important linchpin within Turkey's academic community. The failure prediction models with discriminant 
analysis were calculated in 25 successful and 14 unsuccessful enterprises using 19 financial ratios extracted from the annual balance sheet and income statements published from 1976 to 1980 . Estimates were made by calculating a separate discriminant function for each year. The estimation resulted in a very high rate of 92.9\% accuracy a year before the bankruptcy prediction; thus, it is recommended for a company as an early warning system.

Aktaş (1993) conducted the most comprehensive study in terms of both content and techniques. The research used an unpaired sampling method with 25 unsuccessful and 35 successful industrial companies from 1980 to 1989 for the financial distress estimation. Linear and quadratic discriminant analysis, linear multiple regression model, probit and logit methods, and 23 financial ratios were used in the failure model. Aktaş (1993) observed that the explanatory power of one, two, and three years before financial failure was statistically significant. For example, the model's explanatory power was found very significant with a $99 \%$ confidence level. Another important finding was that the financial structure ratios (debt ratios) are the most critical variables in predicting financial failure. Hence, a company with high debt ratios has a higher risk of financial failure. Subsequently, Aktaş et al. (2003) developed financial stress models by comparing the results of analytic methods such as multiple regression, discriminant analysis, logit analysis, and an ANN. Aktaş compared the multivariate statistical techniques and ANN in a paired sample of 106 enterprises to predict the financial failure one year before the failure. The predictive power of the ANN model was found higher than the multivariate statistical analysis techniques.

Sayılgan and Coşkun (2007) developed a prediction model using industry-adjusted rates and samples from different sectors. Accordingly, a financial prediction model with good predictive power was developed using the logit regression method. The data of unsuccessful non-financial sector companies between 1993 and 2003 were included in the sample. The total sample was divided into two groups: model samples (training samples) and test samples. Two FFP models were developed, one based on adjusted financial ratios as per the corresponding sector averages and the other based on unadjusted financial ratios. In the first stage, a model was developed based on unadjusted variables, and the model's validity was verified using test samples. The same exercise was repeated by replacing the unadjusted variables with the adjusted variables. As a result, the model's predictive power estimated with the adjusted variables yielded an average of $6 \%$ and $8 \%$ better results for one and two years before the financial stress, respectively, compared to the unadjusted variables. Therefore, using the logit regression method with sector-adjusted financial ratios and capital market and macroeconomic variables helps minimize the costs arising from statistical errors.

In a different sector, Ural et al. (2015) developed a financial failure model for food, drink, and tobacco companies based on the BIST data from 2005 to 2012. A model developed with the logistic regression method resulted in FFP with a range of accuracy between $91 \%$ and $74 \%$ up to three years before the financial distress. It was also observed that the logistic regression analysis significantly 
contributed to these successful results.

A study conducted by Aksoy and Boztosun (2018) compared the FFP models using two statistical methods: multivariate discriminant and logistic regression analyses. The FFP model was developed using 126 enterprises operating in the manufacturing industry and listed on the BIST between 2006 and 2009. The research employed 25 financial ratios. Four independent qualitative variables such as the company's operation period, the public issue portion of the capital, capital structure, and the audit firm's reputation were included in the model's estimation. As a result of the analysis, the logistic regression method's usage achieved higher performance on the classification accuracy than a multivariate discriminant analysis for the first and second years before financial failures. There was no different classification performance of the two models when considering the estimation of the third-year performance prior to the financial failure.

To summarize, all three broadly categorized studies in the different economies carried out by different researchers have essential qualities and limitations. There has been constant progress in the use of methods and variables to predict corporate financial failures correctly. Regarding the methods, AI-based models and statistical techniques conditional probabilities have been progressively applied in developing models. Likewise, in addition to the firm-specific financial ratios, many global studies have applied explanatory variables related to financial markets and macroeconomic indicators. Nevertheless, employing various techniques, according to their unique structure of corporate environment and country where they operate, has resulted in the lack of standardized bankruptcy theory in this field.

\section{Developing Financial Failure Prediction Models}

\subsection{Sample Selection and Classification}

The study sample consists of 319 manufacturing companies listed on the BIST between 2007 and 2019. Total selected companies are collectively analyzed and divided into three following groups based on main similar sub-sectoral characteristics in the first stage. Such sub-group sectors are:

- Group I: "Production and Manufacturing Industry Sectors",

- Group II: “Trade, Transportation and other Service Sectors”, and

- Group III: “IT Technology, Administrative, and Support Service Sectors".

Similar characteristics of each sub-sectors are introduced under section four, titled "Empirical Results of the FFP models".

The following Table 1 provides full list of industries according to the sub-group sectors.

The purpose of sector-based grouping is to determine which financial ratios, market and macroeconomic indicators are the most important ones for different industries in the BIST with the help of binary logit analysis as explaining why they serve as good indicators for developing financial failure prediction model. 
Table 1. Full list of industries.

\section{Group I: Production and Manufacturing Industry Sectors}

Agriculture, Forestry and Fishing Mining

Coal Mining

Crude Petroleum and Natural Gas Production

Precious Metal Production

Non-Metallic Other Minerals

Manufacturing Industry

Food, Beverage and Tobacco

Textile, Wearing Apparel and Leather

Wood Products Including Furniture

Paper and Paper Products, Printing and Publishing

Chemicals, Petroleum Rubber and Plastic Products

Non-Metallic Mineral Products

Basic Metal Industries

Fabricated Metal Products, Machinery and Equipment

Other Manufacturing Industry

Construction and Public Works

Group II: Trade, Transportation and other Service Sectors

Wholesale Retail, Trade, Hotels, and Restaurants

Wholesale Trade

Consumer Trade

\section{Electricity Gas and Steam}

Transportation, Telecommunication and Storage

Education, Health, Sports and Other Social Services

Cultural-Entertainment and Recreational Services

Human Health and Social Work Activities

Sports Activities, Amusement and Recreation Activities

Machinery and Equipment Rental Business Activities

Group III: IT Technology, Administrative, and Support Service Sectors

Information Technology

Professional, Scientific and Technical Activities

Legal and Accounting Activities

Activities Of Head Offices; Management Consultancy Activities

Architectural and Engineering Activities; Technical Testing and Analysis

Scientific Research and Development

Advertising and Market Research

Other Professional, Scientific and Technical Activities

\section{Administrative and Support Service Activities}

Travel Agency, Tour Operator, Reservation Service and Related Activities

Security and Investigation Activities

Services To Buildings and Landscape Activities

Office Administrative, Office Support and Other Business Support Activities

Real Estate Activities 
The aim of this study is to reveal the differences of the independent variables in financial failure on the basis of the main sectors with different characteristics. The selected sectors mainly cover primary, secondary, tertiary, and quaternary industries excluding the financial services sector of tertiary industry such as the insurance, banking, financial leasing, factoring, holding, brokerage houses, real estate companies, and investment trusts entities. Finance sector companies have significantly different nature of the business and provide mainly various financial services such as lending, asset management, insurance and more.

The companies' financial data and market indicators were obtained from the BIST and Public Disclosure Platform. The macroeconomic data and indicators were obtained from the Turkish Statistical Institute and the Central Bank of the Republic of Turkey.

Empirical results revealed that these three groups have different underlying influencing explanatory variables, which are more effective on the FFP models for each sub-sector group. Hence, a similar sampling approach is a relatively unique approach compared to cross-industry sampling. This study finds it difficult to build an FFP modeling based on pure single-industry selection due to such industries' limited data size despite constructing relatively more successful FFP models.

In the second stage, the companies were categorized into 162 financial successes with 3779 samples and 157 financial failures with 3390 samples under the following criteria:

1) Declaring bankruptcy, applying for bankruptcy postponement, composition with creditors, and restructuring;

2) Taking losses at least two consecutive years in a row, where equity value declines a minimum of $10 \%$ compared to the previous year;

3) Trading suspension of a company's shares due to the lack of current or accurate financial information;

4) Transferring a company's shares trading to the watch-list market.

The classification of samples and their data based on the companies' semiannual financials covering 13 years is presented in Table 2 and Table 3. Table 2 displays the distribution of the total number of companies as per the financially failed or non-failed Companies for each subsector group. Table 3 shows the quantity of data used in the analysis from the same companies displayed in $\mathrm{Ta}$ ble 2 .

Furthermore, sampling methods for the FFP are classified and reviewed by the following paired groups, including:

1) Training models with the use of $60 \%$ sampling; and

2) Validation test models with $40 \%$ sampling for each sub-sector group, which proportionately represents financially failed and successful companies in each sub-sector.

\subsection{Examined Time Range and Data Distribution}

The study captures 13 years of data between 2007 and 2019 through semi-annual 
Table 2. Companies classifications for sectoral, financial success and failure distribution.

\begin{tabular}{|c|c|c|c|c|c|c|}
\hline & \multicolumn{2}{|c|}{ Total Number of Companies } & \multicolumn{2}{|c|}{ Non-failed Companies } & \multicolumn{2}{|c|}{ Failed Companies } \\
\hline & Total & Percentage (\%) & Total & Percentage (\%) & Total & Percentage (\%) \\
\hline $\begin{array}{l}\text { Group I-Production and Manufacturing } \\
\text { Industry Sectors }\end{array}$ & 234 & 73.35 & 122 & 38.24 & 112 & 35.11 \\
\hline $\begin{array}{l}\text { Group II-Trade, Transportation, and } \\
\text { Other Service Sectors }\end{array}$ & 59 & 18.50 & 22 & 6.90 & 37 & 11.60 \\
\hline $\begin{array}{l}\text { Group III-IT Technology, Administrative } \\
\text { and Support Service Sectors }\end{array}$ & 26 & 8.15 & 18 & 5.64 & 8 & 2.51 \\
\hline All Sectors Companies & 319 & 100.00 & 162 & 50.78 & 157 & 49.22 \\
\hline
\end{tabular}

Table 3. Data samples classification for sectoral, financial success, and failure distribution.

\begin{tabular}{|c|c|c|c|c|c|c|}
\hline & \multicolumn{2}{|c|}{ Total Number of Data Samples } & \multicolumn{2}{|c|}{ Non-failed Data Samples } & \multicolumn{2}{|c|}{ Failed Data Samples } \\
\hline & Total & Percentage (\%) & Total & Percentage (\%) & Total & Percentage (\%) \\
\hline $\begin{array}{l}\text { Group I-Production and Manufacturing } \\
\text { Industry Sectors }\end{array}$ & 5353 & 74.67 & 2896 & 40.40 & 2457 & 34.27 \\
\hline $\begin{array}{l}\text { Group II-Trade, Transportation, and } \\
\text { Other Service Sectors }\end{array}$ & 1256 & 17.52 & 506 & 7.06 & 750 & 10.46 \\
\hline $\begin{array}{l}\text { Group III-IT Technology, Administrative, } \\
\text { and Support Service Sectors }\end{array}$ & 560 & 7.81 & 377 & 5.26 & 183 & 2.55 \\
\hline All Sectors Data Samples & 7169 & 100.00 & 3779 & 52.71 & 3390 & 47.29 \\
\hline
\end{tabular}

financial statements. The distribution of the data and number of companies based on the main sector groups' classification is displayed in Table 4.

It is worth clarifying that the year with the highest number of failed and non-failed companies observed were counted as total companies of each sub-sector group and presented in the total breakdown column of Table 4. For example, the highest observed number of financially 37 failed companies in 2012 while 22 non-failed companies in 2014 were counted for the analysis of group-II companies between 2007 and 2019.

As per the general practice in the literature, the year with the highest number of financial failures was adapted as the base year to estimate FFP models. Therefore, the years 2012 for Group I and II companies and 2013 for Group III companies were identified as the starting years for the "FFP model calculation" for three main sectors.

\subsection{Selection of Variables}

A relevant approach to address the missing data and outliers was adopted for the reliability of the study results, following the companies' classification as per the sectoral, financial success, and failure distribution. Regarding missing values, an average of more than $5 \%$ missing data related to each variable is set as a benchmark for removing the independent variable from the analysis. Table 5 below indicates how many independent variables with more than $5 \%$ missing data were 
Table 4. Distribution of data (7169) and number of firms (319) between 2007 and 2019.

\begin{tabular}{|c|c|c|c|c|c|c|c|c|c|c|c|c|}
\hline & \multicolumn{4}{|c|}{ Group I } & \multicolumn{4}{|c|}{ Group II } & \multicolumn{4}{|c|}{ Group III } \\
\hline & \multicolumn{2}{|c|}{$\begin{array}{c}\text { Failed } \\
\text { companies }\end{array}$} & \multicolumn{2}{|c|}{$\begin{array}{l}\text { Non-failed } \\
\text { companies }\end{array}$} & \multicolumn{2}{|c|}{$\begin{array}{c}\text { Failed } \\
\text { companies }\end{array}$} & \multicolumn{2}{|c|}{$\begin{array}{l}\text { Non-failed } \\
\text { companies }\end{array}$} & \multicolumn{2}{|c|}{$\begin{array}{c}\text { Failed } \\
\text { companies }\end{array}$} & \multicolumn{2}{|c|}{$\begin{array}{l}\text { Non-failed } \\
\text { companies }\end{array}$} \\
\hline Year & $\begin{array}{c}\text { Num. } \\
\text { of Data* }\end{array}$ & $\begin{array}{l}\text { Num. o } \\
\text { Firms }\end{array}$ & $\begin{array}{l}\text { Num. } \\
\text { of Data }\end{array}$ & $\begin{array}{l}\text { Num. of } \\
\text { Firms }\end{array}$ & $\begin{array}{l}\text { f Num. } \\
\text { of Data }\end{array}$ & $\begin{array}{l}\text { Num. of } \\
\text { Firms }\end{array}$ & $\begin{array}{l}\text { Num. } \\
\text { of Data }\end{array}$ & $\begin{array}{l}\text { Num. of } \\
\text { Firms }\end{array}$ & $\begin{array}{l}\text { f Num. } \\
\text { of Data }\end{array}$ & $\begin{array}{l}\text { Num. of } \\
\text { Firms }\end{array}$ & $\begin{array}{l}\text { Num. } \\
\text { of Data }\end{array}$ & $\begin{array}{c}\text { Num. of } \\
\text { Firms }\end{array}$ \\
\hline 2007 & 147 & 77 & 176 & 90 & 50 & 28 & 22 & 13 & 12 & 6 & 19 & 10 \\
\hline 2008 & 161 & 86 & 187 & 97 & 58 & 30 & 30 & 17 & 13 & 7 & 21 & 11 \\
\hline 2009 & 181 & 97 & 199 & 102 & 63 & 33 & 35 & 18 & 14 & 7 & 24 & 13 \\
\hline 2010 & 203 & 108 & 211 & 108 & 68 & 35 & 38 & 20 & 14 & 7 & 27 & 14 \\
\hline 2011 & 214 & 109 & 222 & 114 & 69 & 36 & 40 & 20 & 15 & 8 & 28 & 14 \\
\hline 2012 & 214 & 111 & 231 & 117 & 70 & 37 & 40 & 20 & 16 & 8 & 28 & 14 \\
\hline 2013 & 211 & 111 & 235 & 118 & 66 & 33 & 40 & 20 & 16 & 8 & 28 & 14 \\
\hline 2014 & 206 & 111 & 238 & 120 & 62 & 32 & 42 & 22 & 15 & 8 & 29 & 15 \\
\hline 2015 & 201 & 112 & 240 & 122 & 56 & 29 & 44 & 22 & 14 & 7 & 31 & 16 \\
\hline 2016 & 191 & 111 & 241 & 122 & 51 & 26 & 44 & 22 & 14 & 7 & 34 & 18 \\
\hline 2017 & 184 & 93 & 240 & 122 & 49 & 25 & 44 & 22 & 14 & 7 & 36 & 18 \\
\hline 2018 & 174 & 88 & 239 & 122 & 45 & 23 & 44 & 22 & 14 & 7 & 36 & 18 \\
\hline 2019 & 170 & 85 & 237 & 122 & 43 & 22 & 43 & 22 & 12 & 6 & 36 & 18 \\
\hline Total Breakdown & 2457 & 112 & 2896 & 122 & 750 & 37 & 506 & 22 & 183 & 8 & 377 & 18 \\
\hline Total Number of Data & \multicolumn{4}{|c|}{5353} & \multicolumn{4}{|c|}{1256} & \multicolumn{4}{|c|}{560} \\
\hline Total Number of Firms & \multicolumn{4}{|c|}{234} & \multicolumn{4}{|c|}{59} & \multicolumn{4}{|c|}{26} \\
\hline \multicolumn{5}{|c|}{ Total Number of Unsuccessful Firms } & 157 & Total $\mathrm{Nu}$ & imber of & Unsucc & cessful Fi & irms & & 162 \\
\hline
\end{tabular}

${ }^{\star}$ It covers the number of semi-annual data of each firm.

Table 5. Independent variables' elimination.

\begin{tabular}{lccc}
\hline & \multicolumn{3}{c}{ Sectors } \\
\cline { 2 - 4 } & Group I & Group II & Group III \\
\hline Financial Ratios and Market Indicators/Indices & 40 & 40 & 40 \\
Macroeconomic Parameters & 14 & 14 & 14 \\
Total Variables & 54 & 54 & 54 \\
Eliminated Variables After 5\% Missing Data (-) & 13 & 17 & 14 \\
Remaining Variables & 41 & 37 & 40 \\
Eliminated Variables After Clustering (-) & 32 & 27 & 31 \\
Wide Variables Group & 9 & 10 & 9 \\
\hline
\end{tabular}

removed from each sector group's total number of factors. All removed variables were only related to "the Financial Ratios and Market Indicators/Indices." As shown in Table 5, after deducting 5\% of missing data, the remaining factors consist of 41,37 , and 40 independent variables belonging to the Group I, II, and 
III sectors, respectively.

Following the initial elimination stage, the outliers related to the remaining independent variables were detected. The value modification method was applied to the outliers with the Winsorized rate of $2.1 \%$, replaced with substituted values (Kwak and Kim, 2017).

A clustering technique similar to the factor analysis was used to create more meaningful subgroups of independent variables as a pre-processing step. Clustering and iterative algorithms - the PROC VARCLUS software procedurewere applied to cluster and reduce the remaining variables under significant groups.

As shown in Table 5 under "Wide Variables Group," an average of nine but totaling eighteen most significant independent variables for each sector group (I, II, and III) were selected after the clustering process. The clustering technique clusters variables into two central units. The first unit consists of highly correlated variables titled "R-squared with Own Cluster". The second unit contains possibly less-correlated explanatory variables in other clusters titled " $1-R^{\star \star} 2 \mathrm{Ra}$ tio" in Table 6. A reduction in the number of variables is achieved by selecting one of the first units' highly correlated variables while having a less-correlated variable in the second unit at the end of each clustering stage (Sanche and Lonergan, 2006).

A complete list of selected independent (explanatory or predictive) variables can be called a "wide variables group" of sorts (Table 6). As can be seen from the breakdown, each sector Group I, II, and III shares the same explanatory variable as follows:

1) Gross profit margin (gross sales profit/net sales) indicating the relationship between sales and profits,

2) Macroeconomic indicator (non-performing loans/total cash loans ratio).

Sector Groups I and II have the following similar explanatory variables:

3) Fixed assets turnover rate (net sales/fixed assets) can also be called sales turnover ratio,

4) Return-on-assets (net profit/total assets) indicating the relationship between profit and capital,

5) Macroeconomic indicators (interest rates for banks' loans),

6) Stock market data (BİST Industrial Index).

Sector Groups I and III have the following similar explanatory variable:

7) Equity Ratio (total equity/total assets), which is part of the financial structure ratios.

Similarly, sector Groups II and III have the following similar explanatory variable:

8) Return on Equity Before Tax (Profit Before Tax (PBT)/Equity) indicating the relationship between profit and capital.

Only sector Group I has the following unique explanatory variables:

9) Current ratio (current assets/current liabilities). 
Table 6. Wide variables group.

\begin{tabular}{|c|c|c|c|c|}
\hline & \multicolumn{2}{|c|}{ Explanatory Variables } & $\begin{array}{l}\text { R-squared with } \\
\text { Own Cluster }\end{array}$ & $1-R^{* * 2}$ Ratio \\
\hline \multicolumn{5}{|l|}{ Liquidity Ratios } \\
\hline Group I & Current Ratio & Current Assets/Current Liabilities & 0.8933 & 0.1634 \\
\hline Group II & Acid-Test Ratio & $\begin{array}{c}\text { Current Assets Less Stocks/Current } \\
\text { Liabilities }\end{array}$ & 0.8765 & 0.1511 \\
\hline \multicolumn{5}{|c|}{ Financial Structure Ratios (Borrowing Rates) } \\
\hline Group I & Short-Term Leverage & Short-Term Liabilities/Total Liabilities & 0.8731 & 0.1599 \\
\hline Group II & Debt Ratio & Total Debt/Total Assets & 0.8936 & 0.1522 \\
\hline Group III & Fixed assets to equity ratio & Fixed assets/equity & 0.7307 & 0.3153 \\
\hline Group I \& III & Equity Ratio & Total Equity/Total Assets & $0.8943 \& 0.8722$ & $0.1947 \& 0.174$ \\
\hline \multicolumn{5}{|c|}{ Debt Service Coverage Ratio } \\
\hline Group III & Interest Coverage Ratio & EBIT/Interest Expenses & 1 & 0 \\
\hline \multicolumn{5}{|l|}{ Sales Turnover } \\
\hline Group II & Asset Turnover & Net Sales/Total Assets & 0.7848 & 0.2856 \\
\hline Group III & Equity Turnover Ratio & Net Sales/Equity & 0.8006 & 0.3339 \\
\hline Group I \& II & Fixed Assets Turnover Rate & Net Sales/Fixed Assets & $0.892 \& 1$ & $0.1178 \& 0$ \\
\hline \multicolumn{5}{|c|}{ Relationship Between Profit and Capital } \\
\hline Group I \& II & Return-on-Assets & Net Profit/Total Assets & $0.7903 \& 0.6216$ & $0.2533 \& 0.506$ \\
\hline Group II \& III & Return on Equity Before Tax & Profit Before Tax (pbt)/Equity & $1 \& 0.8379$ & $0 \& 0.173$ \\
\hline \multicolumn{5}{|c|}{ Relationship Between Sales and Capital } \\
\hline Group I \& II \& III & Gross Profit Margin & Gross Sales Profit/Net Sales & $\begin{array}{c}0.9928 \& 0.718 \& \\
0.8671\end{array}$ & $\begin{array}{c}0.0094 \& 0.3265 \& \\
0.1599\end{array}$ \\
\hline \multicolumn{5}{|c|}{ Financial Markets \& Macroeconomic Indicators } \\
\hline Group III & The Produ & cer Price Index (PPI) & 0.6839 & 0.3561 \\
\hline Group I \& II & Interest $\mathrm{Ra}$ & tes for Banks' Loans & $0.6785 \& 0.7044$ & $0.5288 \& 0.4885$ \\
\hline Group I \& II \& III & Non-Performing L & oans/Total Cash Loans Ratio & $\begin{array}{c}0.8016 \& 0.8004 \& \\
0.8003\end{array}$ & $\begin{array}{c}0.2502 \& 0.252 \& \\
0.2868\end{array}$ \\
\hline \multicolumn{5}{|c|}{ Stock Market Data (BİST Indexes) } \\
\hline Group III & BIST T & echnology Index & 0.9604 & 0.0674 \\
\hline Group I \& II & BİST & ndustrial Index & $0.9443 \& 0.9564$ & $0.0984 \& 0.0618$ \\
\hline
\end{tabular}

10) Short-term leverage (short-term liabilities/total liabilities), which is part of the borrowing ratios.

Only sector Group II has the following unique explanatory variables:

11) Acid-test ratio (current assets minus stocks/current liabilities).

12) Debt Ratio (total debt/total assets).

13) Asset turnover (net sales/total assets), which is part of the sales turnover ratios.

Only sector Group III has the following unique explanatory variables:

14) Fixed assets to equity ratio, which is part of the financial structure ratios.

15) Interest coverage ratio (EBIT/interest expenses), which is one of the debt 
service coverage ratios.

16) Equity turnover ratio (net sales/equity), which is one of the sales turnover ratios.

17) Macroeconomic Indicator, which is the Producer Price Index (PPI).

18) Stock Market indicator, which is BIST Technology Index.

Following the factor analysis by applying the clustering technique, the wide independent variables selected represent financial, market, and macroeconomic factors for each sector group, and cross-sector groups are quite meaningful in terms of academic and business perspectives.

In the next step, the number of selected explanatory variables is further reduced using the stepwise regression method to identify the most valuable final predictors and build effective predictive models for each sector group.

\subsection{Statistical Methods}

After addressing the missing data, outliers and applying the clustering technique to reduce the variables, a further subtraction from a set of nine explanatory variables for each sector group is carried out using the stepwise linear regression method. The stepwise approach is an automatic procedure in filtering the variables that efficiently create the predictive models for each sector group.

Furthermore, discriminant analysis (DA) was used as the first technique to compare the logistic regression (LR) on the expected outcomes of FFP models. Accordingly, the DA was tested to maximize the intergroup variance and examine the best classification between financially failed and non-failed companies on the samples selected from Group I "Production and Manufacturing Industry Sectors" between 2007 and 2012. Nevertheless, the DA's validity performance tests were not achieved because of not meeting required assumptions such as homogeneity of covariance matrices and normal distribution of data related to the explanatory variables.

Alternatively, the LR method, which does not require such assumptions of the $\mathrm{DA}$, is used in developing FFP models. LR has advanced in modeling the dependent variables as binary, ordinal, or categorical, and the independent variables can be of any category. Moreover, the classification capacity is likely to be better than the model of DA.

Hence, this study used LR as a statistical methodology to determine which models provide independent variables relevant to assessing failure risk and interpreting individual coefficients' significance. In addition, LR as a predictive statistical method is preferred because it successfully defines, classifies, and predicts the relationship between the dependent variables (outcome variable) and independent (predictive or explanatory) variables (Cramer, 2003). LR uses the maximum likelihood estimation method applicable to different data types and produces when estimating the parameters from a random sample. Thus, it is the best accurate estimation than the least-squares estimation method.

In the study, "Logistic Regression" and "Logit Function" are interchangeably used. A logit function is formulated as follows: 


$$
P_{i}=\frac{1}{1+e^{-Z}}=\frac{1}{1+e^{-\left(\beta_{0}+\beta_{1} X_{1} \cdots \beta_{\text {in }} X_{\text {in }}\right)}}
$$

where $P_{i}$ is the probability of failure, $\beta_{i}(1,2,3 \ldots n)$ denote coefficient weights and $X_{i}(1,2,3 \ldots n)$ represent independent variables (financial and macroeconomic ratios). The aim is to determine the $\beta$ values that will make the coefficients of the independent variables meaningful at the maximum probability level. The logit function weighs the independent variables and calculates a Z-Score for each firm as the probability of failure. The model's parameters are estimated using the maximum probability method (Gujarati and Porter, 2009).

The odds' ratios in LR are essential concepts for estimating the constant effect of independent variables $X_{i}$ on the possibility that several financial failure outcomes occurred compared to the number of times financial non-failure occurred. Thus, an odd's ratio is calculated with the exponential value $\left(e^{Z_{i}}\right)$ of the coefficients.

The odds' formula is $e^{Z_{i}}=\frac{P_{i}}{1-P_{i}}$, whereby $Z_{i}$ can be derived from the equation, $Z_{i}=\beta_{0}+\beta_{1} X_{1} \cdots \beta_{i} X_{n}$. The odds' values range from 0 to infinity. If value is greater than 1 , financial failure is most probable than financial non-failure. If the odds' value is less than 1, the financial failure becomes less probable (Cramer, 2003).

In the following sections of the study, the SPSS 24 program, variable coefficients, and exponential values are calculated with the binary logit function by coding " 1 " for "financially failed companies" and " 0 " for "financially non-failing firms." Hence, the training's success and test sampled models' classification and prediction power are interpreted up to 3 years before the failure's year.

\section{Empirical Results of the FFP Models}

\subsection{Group I: Production and Manufacturing Industry Sectors}

The Group I sector has been accepted as the pioneer for economic growth. It is an indicator for a country's development level, leading to developing its sector and other sectors, considering the strong supply chain. The most basic criterion used in defining the Group I sector's characteristic is the production of tangible goods. Production of physical goods means using raw materials as inputs for production in the primary and secondary sectors. The end-products are generated either directly from natural resources or by producing new products from manufactured goods.

The manufacturing industry in Turkey operates at different technological levels in terms of sub-sectors. For example, pharmaceutical, electrical machinery, communication equipment, aircraft, and other device industries require advanced technologies. Other sub-sectors such as agriculture, textile, clothing, forestry products, paper products, oil and coal by-products, cement, iron, and other metal goods require moderate technologies (Polat, 2011).

Compared to other sectors (Group II and III), the manufacturing sector's 
unique characteristics create some differences in the companies' balance sheets and financials. Consequently, the differentiation can be observed in the financial ratios regarding cash flow, inventory turnover, operating costs, and profitability. These differences may naturally result in selecting independent variables for estimating the FFP model, as similarly observed in selecting the "wide variables group".

\subsubsection{Estimation Coefficients and Models}

Following the selection of nine explanatory variables as "wide variables group" at the pre-processing step for the Group I sector, the explanatory variables were further reduced to the most significant four variables using the stepwise regression procedure. The regression coefficients $(\beta)$ of the logit models and associated odds ratios up to three years before the financial failure date are presented in Table 7.

Each coefficient changes the odds ratio by a multiplicative amount, which is the value of $e^{-\beta}$, as shown in the column "Odds Ratio" representing "Exp. $(\beta)$ ".

As observed from our results in Table 7, there is a general pattern between the sign of coefficients and odds ratios (Exp. $(\beta))$ in estimating the occurrence likelihood of the FFP. If a coefficient sign is negative, the odds ratio is less than one, displaying a reverse relationship between an increase in the variable's value and a decrease in the probability of financial failures. The converse is true if the sign of the coefficients is positive.

The hypothesis of whether the explanatory variables contribute significantly to the model was examined with the help of the coefficients $(\beta)$ of the logit models and the associated odds ratios table concerning "up to three years prior to the financial failure date".

H0: $\beta=0$ (The variables selected do not have a significant contribution to the model)

H1: $\beta \neq 0$ (The variables selected have a significant contribution to the model)

Since the significance values (sig.) or the $p$-value of the four explanatory variables selected were estimated to be less than 0.05 (Alpha $<0.05$ ), the hypothesis was tested at a $95 \%$ confidence level (Confidence Interval). The significance values (sig.) with less than $5 \%$ reject the $\mathrm{H} 0: \beta=0$ (null) hypothesis. These results

Table 7. Coefficients $(\beta)$ of the logit models and the associated odds ratios for group I sector.

\begin{tabular}{cccccccccc}
\hline & \multicolumn{4}{c}{} & \multicolumn{3}{c}{ Years Before the Financial Failure Date } \\
\cline { 2 - 10 } & \multicolumn{2}{c}{ Average Values } & \multicolumn{2}{c}{ One Year } & \multicolumn{2}{c}{ Two Years } & \multicolumn{2}{c}{ Three Years } \\
\hline & $\beta$ & Odds Ratio & $\beta$ & Odds Ratio & $\beta$ & Odds Ratio & $\beta$ & Odds Ratio \\
\hline Equity Ratio (ER) & -0.024 & 0.976 & -0.024 & 0.976 & -0.025 & 0.975 & -0.022 & 0.978 \\
Short-Term Leverage (STL) & -1.241 & 0.291 & -1.165 & 0.312 & -1.39 & 0.249 & -1.167 & 0.311 \\
Return-On-Assets (ROA) & -0.097 & 0.908 & -0.121 & 0.886 & -0.093 & 0.911 & -0.076 & 0.927 \\
BIST Industrial Index (BII) & 0.180 & 1.197 & 0.151 & 1.162 & 0.194 & 1.214 & 0.195 & 1.215 \\
Constant & 1.579 & 4.950 & 1.736 & 5.676 & 1.718 & 5.572 & 1.282 & 3.603 \\
\hline
\end{tabular}


demonstrated that the overall model was significant, and thus, the $\mathrm{H}=0$ hypothesis was rejected. As can be seen from Table 7, the relevant explanatory variables consisted of ER, STL, ROA. BIST industrial index (BII) was found to be significant in models calculated one, two, and three years before the financial failure date for the Group I sector.

Based on Table 7, the logit method that produces the following prediction model for the average coefficients $(\beta)$ value of one, two, and three years before the financial failure date is presented as follows:

$$
\ln \left(\frac{p}{1-p}\right)=1.579-0.024 \mathrm{ER}-1.241 \mathrm{STL}-0.097 \mathrm{RoA}+0.180 \mathrm{BII}
$$

The coefficients with negative signs illustrated that a unit change in the explanatory variables (predictors) such as ER, STL, ROA reduced the company's financial failures by $0.976,0.291$, and 0.908 odd ratios, respectively while controlling for the other predictors. In contrast, the coefficients with positive signs indicated that a unit change in BII increased the probability of the company's financial failures by a factor of 1.197 odd ratios. Hence, it seems that there is a parallel change between the stock market (BII) and industrial companies' financial failures listed on the BIST in the prediction model.

Nonetheless, given the coefficient signs with the average odds rate over three years, other independent variables (ER, STL, ROA) were found to be statistically significant, reducing financial failure probability at a reasonably acceptable level.

\subsubsection{Predictive Power of the Models}

The binary LR models are developed as a "trained modeP" for the FFP based on 60 percent sampling companies. The "test models" were also developed and tested on a group of companies different from those used to produce the trained models' parameters as validation tests using $40 \%$ sampling.

Accordingly, both models' predictive accuracy or classification power are evaluated and compared with the results obtained from classification Table 8.

Table 8. Predictive power of trained and test models up to three years before the group I sector's financial failure date.

\begin{tabular}{cccccc}
\hline & & \multicolumn{4}{c}{ Years Before the Financial Failure Date } \\
\cline { 3 - 6 } & & Average & One Year & Two Years & Three Years \\
\cline { 3 - 6 } & & \multicolumn{4}{c}{ Correct Percentage } \\
\hline \multirow{2}{*}{ Trained Model } & Fon-failed companies & 74.8 & 75.0 & 74.5 & 74.8 \\
& Failed companies & 67.3 & 69.8 & 68.6 & 63.4 \\
& Overall Percentage & 71.3 & 72.5 & 71.7 & 69.6 \\
\hline \multirow{3}{*}{ Test Model } & Non-failed companies & 73.0 & 71.7 & 74.2 & 73 \\
& Failed companies & 68.4 & 65.9 & 66.3 & 73 \\
& Overall Percentage & 70.8 & 68.9 & 70.4 & 73 \\
\hline
\end{tabular}


The predictive power of the trained models' results is highly significant at the level of $72.5 \%, 71.7 \%$, and $69.6 \%$ in the first, second, and third years before the failure date, respectively. Thus, the first year's classification power with $72.5 \%$ was slightly more successful than the models developed in the second and third years prior to the failure date. Similar results are observed in academic studies on this subject. Likewise, the test models' prediction power was created to validate the trained models' results. As can be seen from Table 8, the average classification rate of test models with $70.8 \%$ validates the trained models' results of $71.3 \%$.

When measuring the predictive power of both trained and test models, overall successful results were obtained with an average of $71.3 \%$ and $70.8 \%$, respectively, in classifying and predicting financial failures for this group of companies up to three years before the failures.

Another approach of interpreting the LR models' classification power represents the cost of Type I and Type II errors. A serious issue for the external stakeholders, especially financiers, is the cost of classifying the financially failed companies as successful ones (Type II error) because the overriding objective of the financiers is to reduce Type II error and maximize sensitivity. As per Table 8, an average Type I error (classifying the successful company as unsuccessful) and Type II error (classifying the financially failed companies as successful) for trained model's companies were averagely calculated as $25.2 \%$ (100 - 74.8) and $32.7 \%$ (100 - 67.3) respectively. Some improved results on Type II error with $31.6 \%$ were obtained from the test model, which contributed to the validation of the trained models and improved reasonably overall predictive accuracy of the FFP model.

\subsubsection{Variables Interpretation for the Group I Sector}

Given the findings so far, the following interpretation has been made for the model's independent variables.

BIST Industry Index (BII): The stepwise method selected the BII among the four statistically significant variables. Considering the coefficient value and a factor of 1.197 odd rates, BII increases the financial failures for this sector. The results are reasonable and unique when considering the financial risk impact of this parameter on the predicting model. It seems that there is a similar movement between the BII and industrial companies' financial failures in the prediction model.

It is unnecessary to establish a direct cause-effect relationship between the two variables, as the factors affecting the change in financial failure may differ directly from the factors affecting the industrial index change. The increase in the BII is largely influenced by macroeconomic factors, while the financial failures are affected by firm-specific or unsystematic factors. For example, despite the growing economic problems, financial difficulties, loan restructuring, and bankruptcies observed in Turkey since 2008, the BII industry index has continued to recover from the short-lived adverse effects of the crisis due to the im- 
plementation of the various fiscal stimulus programs, especially for manufacturing sectors.

Therefore, a parallel occurrence of the increase in the industrial index and financial failures in the FFP model is considered acceptable.

Equity Ratio (ER): The total Equity-to-Total Assets is a formula among the financial structure ratios indicating how the equity finances much of the business assets. The ER is an important explanatory variable with the highest coefficient value, which reduces the risk of financial failure by an average probability factor of 0.976 odds ratio for the companies in the Group I sectors.

Funding the total business assets is carried out by two primary sources: the owner's equity and the borrowing. Therefore, evaluating how the full spectrum of financial resources is used in funding assets for financial failure predictions is crucial. It is essential to compare the efficient utilization of equity and borrowings as funding resources. In general, companies with higher ERs have less external financial resources and debt service costs than lower ERs.

The ERs have a reverse impact on this FFP model compared with the total debt-to-total assets ratio, and an instrument used to analyze a company's solvency. An increase in the ER significantly reduces the risk of business failure due to optimum utilization of equity resources with low debt service costs.

Moreover, a listed company trading in the stock exchange with a higher equity ratio is perceived as more credible and sustainable than its peers and attracts more attention from equity investors. Hence, the ERs with a coefficient with a negative sign and a high odds (exponential) ratio indicate a good measure in predicting companies' financial failures up to three years before the financial failure date.

Return-On-Assets (ROA): The ROA indicates a company's ability to profit from its operations. The ROA, formulated by dividing net profit after tax by total assets, is widely used in profitability analysis by all stakeholders to assess how a company's earnings are generated. In this sense, ROA is also related to productivity rates, as it shows how well companies use their assets to make a profit.

This research confirms that ROA reduces the risk of financial failure among the profitability ratios with the average probability factor of 0.908 odd ratios and is the second major predictor of financial failure in the Group I sector model. The ROA is an important ratio, most commonly applied as an explanatory variable in predicting financial failure models. Some specialized literature shows that the asset profitability ratio was among the important independent variables as observed in financial failure studies of Beaver (1966), Deakin (1972), and Libby (1975). The net profit to total assets ratio was also an effective explanatory variable on developing FFP models in the Turkish literature (Sayllgan and Coşkun, 2007).

A higher ROA indicates more effective and profitable management of the company's assets. Hence, as one of the critical profitability ratios, the ROA is used as risk evaluation criteria by the shareholders, investors, and financial institutions when providing capital and loans in their decision-making process. In 
short, high ROA is an important result of high solvency and strong sustainability; its effect on reducing financial failure for companies is significant.

Short-Term Leverage (STL): The STL or current liability ratio is formulated as the current liabilities-to-total liabilities. It measures the short-term proportion of total liabilities that become due in less than one fiscal year.

Generally, short-term debts consist of trade, corporate overdraft account, interest, taxes, bills payables, accrued expenses, and short-term loans. Unlike other leverage ratios, the current liability ratio is primarily regarded as a secondary measure of liquidity rather than the ratio measuring its ability to pay for its liabilities. Therefore, increasing the STL activities boosts the current ratio, one of the leading liquidity measurements. Also, the STL helps to facilitate the sales activities and the inventory turnover of a company. Thus, an increase in the current liabilities raises the current assets, which causes a growth in liquidity position and contributes to the healthy development of the company's operations.

Subsequently, the logit model identifies the current liability ratio as the third significant predictor with an average factor of 0.291 odd ratios up to three years before this group of companies' financial failures. Finding on the STL accommodates another range of factors when predicting financial failure for industrial enterprises.

\subsection{Group II: Trade, Transportation, and Other Service Sectors}

The Group II sector's common feature is selling consumer goods or services through the supply chain and multiple distribution channels to reach the ultimate consumers. The delivery of service and products in this group sector largely depends on its service quality. It is also worth highlighting that the operation and cost structure of the trade, transport, and service sectors have been changing rapidly with fast digitalization and globalization, reaching broader national and international markets through online shopping.

Therefore, the costs paid for the services provided and the number of sales executed constitute a significant part of the companies' total costs. Moreover, financial ratios associated with profitability and liquidity are relatively more relevant indicators that show how quickly a company can turn over its stocks and increase its sales with the right pricing policy. It is expected that some unique financial ratios for Group II sector companies can be important predictors in developing FFP models.

\subsubsection{Estimation Coefficients and Models}

Similar steps were taken to construct the logit models' regression coefficients ( $\beta$ ) and associated odds ratios for Group II sectors over three years before the financial failure date. The results are presented in Table 9 below. After the pre-processing step, ten independent variables were reduced to the four most significant explanatory variables with the stepwise method using clustering and iterative algorithms.

With the coefficients' help, the hypothesis concerning whether the variables 
Table 9. Coefficients $(\beta)$ of the logit models and the associated odds ratios for group II sector.

\begin{tabular}{cccccccccc}
\hline & \multicolumn{1}{c}{} & \multicolumn{5}{c}{ Years Before the Financial Failure Date } \\
\cline { 2 - 9 } & \multicolumn{2}{c}{ Average Values } & \multicolumn{2}{c}{ One Year } & \multicolumn{2}{c}{ Two Year } & \multicolumn{2}{c}{ Three Year } \\
\cline { 2 - 9 } & $\beta$ & Odds Ratio & $\beta$ & Odds Ratio & $\beta$ & Odds Ratio & $\beta$ & Odds Ratio \\
\hline Gross Profit Margin (GPM) & -0.025 & 0.975 & -0.029 & 0.971 & -0.020 & 0.980 & -0.027 & 0.974 \\
Return on Assets (ROA) & -0.057 & 0.945 & -0.052 & 0.950 & -0.054 & 0.948 & -0.064 & 0.938 \\
Return on Equity Before Tax (ROE) & -0.438 & 0.647 & -0.346 & 0.707 & -0.427 & 0.652 & -0.542 & 0.582 \\
Debt Ratio (DR) & -1.023 & 0.373 & -1.143 & 0.319 & -1.262 & 0.283 & -0.663 & 0.516 \\
Constant & 1.947 & 7.061 & 2.106 & 8.216 & 1.929 & 6.884 & 1.805 & 6.083 \\
\hline
\end{tabular}

contribute significantly to the model over the three years before the financial failure is examined.

H0: $\beta=0$ (The variables selected do not have a significant contribution to the model)

H1: $\beta \neq 0$ (The variables selected have a significant contribution to the model)

Considering the $p$-value (sig.) of four explanatory variables with less than 0.05 percent and the confidence level of 95\%, the H0: $\beta=0$ (null) hypothesis was rejected. Accordingly, all four parameters were useful to the model, as indicated by their respective significance values (sig.). These results proved that the overall model during the given period is significant. As stated previously, the coefficients' sign shows the nature of the relationship between the odd ratio and the FFP.

As shown in Table 9, all four parameters, namely, GPM, ROA, return on equity, and DR, are useful to the FFP model during the respective period of one, two, and three years before the financial failure for this sector's companies.

The ROA reduces the risk of financial failure at a high rate in both sectors (Group I and II). Other independent variables such as GPM, ROE, and DR are different from the previous Group I sector in estimating their respective FFP models. Furthermore, the majority (three) of the explanatory variables are selected from profitability ratios. Only one explanatory variable is related to the borrowing ratio. Independent variables, including financial, profitability, and market variables, are more diversified in estimating the FFP for the Group-I sector than the Group II sector. These results also reveal that a sector-based study generates more sector-specific variables in developing prediction models.

After the logit analysis, the following formula was developed for the average coefficients $(\beta)$ value of one, two, and three years before the financial failure.

$$
\ln \left(\frac{p}{1-p}\right)=1.947-0.025 \mathrm{GPM}-0.057 \mathrm{RoA}-0.438 \mathrm{ROE}-1.023 \mathrm{LA}
$$

Considering all coefficients' negative signs for three years before the failure, all factors of the explanatory variables decrease the predicted probability of financial failures in the models. Considering the odd values, a one-unit increase in the GPM, ROA, ROE, and DR reduces the failure risk probability by the factors of 
$0.975,0.945,0.647$, and 0.373 odds ratios, respectively over the course of three years before the failures.

It is observed that there were some parallel movements between the profitability-related variables (GPM, ROA, ROE) and the leverage-related variable (LA). Thus, debt utilization reduced financial failure risk while increasing equity returns to a certain optimum level. Such an outcome has no contradiction with business expectations.

Besides, the models' odds ratios showed that the prediction success one year before the failure is similar to the prediction success of two and three years before failure, which is in line with the business practice observed for this sector's companies.

\subsubsection{Predictive Power of the Models}

The binary LR model was used to develop a "trained model" using $60 \%$ sampling data obtained from the companies selected. Further, the "test modes" were also developed with the help of a $40 \%$ different sampling group of companies to validate Group II Sector's companies' parameters for three years before the failures.

Consequently, both models' predictive accuracy and classification power were estimated, and the results are presented in the classification Table 10.

An average of $86.6 \%$ of predictive power for failed companies regarding the trained models was validated by an average of $90.9 \%$ of the test models' predictive power due to comparatively high volumes of samples used in the test model estimation. Successful results were obtained from both trained and test models with an average of $68.5 \%$ and $76.8 \%$, respectively, in classifying and predicting financial failures over the same periods.

Regarding the classification power of the LR models, Type I error (classifying the successful company as unsuccessful), and Type II error (classifying the companies who experienced financial failure as successful) for trained and test models' companies were averagely estimated as $31.5 \%(100-68.5)$ and $23.2 \%$ (100 - 76.2) respectively.

Table 10. Predictive power of trained and test models up-to three years before the group II sector's financial failure date.

\begin{tabular}{cccccc}
\hline & & \multicolumn{4}{c}{ Years Before the Financial Failure Date } \\
\cline { 3 - 6 } & & Average & One Year & Two Years & Three Years \\
\cline { 3 - 6 } & & \multicolumn{4}{c}{ Correct Percentage } \\
\hline \multirow{3}{*}{ Non-failed companies } & 36.7 & 40.5 & 27.9 & 41.8 \\
\cline { 3 - 6 } Trained Model & Failed companies & 86.6 & 89.3 & 86.1 & 84.3 \\
& Overall Percentage & $\mathbf{6 8 . 5}$ & 71.7 & 64.8 & $\mathbf{6 8 . 9}$ \\
\hline \multirow{3}{*}{ Test Model } & Non-failed companies & 47.8 & 43 & 59 & 41.3 \\
& Failed companies & 90.9 & 87.6 & 92.2 & 92.9 \\
& Overall Percentage & $\mathbf{7 6 . 8}$ & 72.4 & $\mathbf{8 1 . 5}$ & $\mathbf{7 6 . 6}$ \\
\hline
\end{tabular}


Likewise, Type II error for failed companies in the test model with an average of $9.1 \%$ (100 - 90.9) was very low, which contributed to the validation of the trained models and improved the overall predictive accuracy of the FFP for Group II companies.

\subsubsection{Variables Interpretation for the Group II Sector}

After the clustering exercise performed in the initial analysis, ten explanatory variables or "wide variable groups" were reduced to four by using LR to limit the sample size for this group of companies.

The independent variables primarily consisted of profitability ratios such as GPM, ROA, and ROE associated with the companies' capital and sales. The DR is related to the companies' loans. The profitability-related variables (GPM, ROA, ROE) and leverage-related variables (DR) reduced the risk of financial failures with the estimated probabilities presented in Table 9. Likewise, the four explanatory variables provided a high FFP accuracy for this group of companies.

Gross Profit Margin (GPM) indicates a company's ability to generate gross profit from its sales or services. For the businesses in these sectors, the gross profit margin was measured as gross sales profit-to-net sales and estimated as a most effective independent variable reducing the risk of financial failure by an average probability factor of 0.975 odds ratio over three years before the failures.

Gross profit is the remaining income after deducting direct costs such as direct supplies, equipment, labor, and depreciation, excluding fixed costs. A high gross margin indicates that a company efficiently manages its sales and services while converting direct costs into revenues. Therefore, providing a high volume of services or achieving high sales with well-managed direct costs can ensure a high GPM and ultimately reduce the risk of financial failure for the Group II sector's companies. The GPM and the ROA are the most common explanatory variables widely effective in predicting financial failures (Sayılgan and Coşkun, 2007).

Return on Assets (ROA): As explained in detail previously, the ROA ratio was calculated as the commonly used independent variable that reduced the companies' risk of financial failure in Group I and II sectors. This ratio shows an enterprise's ability to generate profits from its activities and is a critical variable in predicting financial failure at the highest impact levels for both industry groups.

As an explanatory variable, the ROA ratio was found to reduce the risk of financial failure with the average probability factor of 0.975 and 0.907 odds ratios for both Group-I and II sector companies, respectively.

Return on Equity Before Tax (ROE): ROE is the third most effective independent variable in estimating the FFP model reducing the risk of financial failure by an average probability factor of 0.647 odds ratio for this sector over three years. According to the study carried out by Elam (1975), the ROE ratio is one of the most commonly used explanatory variables in the literature predicting companies' failures (Chen and Shimerda, 1981).

The ROE is an equity profitability ratio, which fundamentally measures the 
company's net assets' return. The equity profitability ratio indicates how much pre-tax profit a shareholder or investor can make for each invested capital unit. This ratio is also a performance measurement of a company's management, indicating how efficiently capital resources are used. Hence, the higher ROE can be considered the better performance for the company's management.

Nevertheless, considering the contribution of the external resources (debt) to the company's profit, higher ROE should be assessed in the context of high financial leverage and its possible impact on the company's solvency comparable with the same sector's indicators. Therefore, it is best to compare high ROEs with similar debt or leverage levels of companies operating in the same industry.

Debt Ratio $(D R)$ : The debt ratio is a company's leverage ratio, formulated as the total debt ratio to total assets. It is observed that the DR is the fourth effective independent variable in estimating the FFP model. It moderately reduced the risk of financial failure by the average factor of 0.374 odds ratio in the Group II sector over three years before the failure.

A company's total assets are financed by debt or equity. If the DR value is one, it means the debt funds a significant portion of total assets. Alternatively, less than $1 \%$ DR value means the equity contribution to the total financing assets is significant. Therefore, there is no single DR benchmark rate across industries. Generally, Group-I sector companies have much higher debt ratios than Group II sector companies, which have a comparatively less capital-intensive balance sheet structure.

Although an increase in the DR could be considered a risk associated with a company's financial strength, a low-level debt ratio indicates conservative financing. Hence, there is no significant risk of financial failure as long as the increase occurs in parallel with the growth of the profitability-related variables (GPM, ROA, ROE).

In summary, it was observed that the independent variables representing financial ratios in the models developed for the companies in the Group II sector were found in conformity with the practice of different stakeholders when predicting the FFP model for the Group I sector enterprises at the acceptable levels.

\subsection{Group III: IT Technology, Administrative, and Support Service Sectors}

The Group III section consists of mainly IT and service-related sub-sectors, such as software, telecom, hardware, semiconductors, tourism, travel arrangements, administration, and cleaning activities. This industry segment usually has three common characteristics: 1) common outputs produced are intangible, technological, and labor-intensive facilities depending on the quality performance of services, information, professionalism, scientific and technical activities. 2) Unlike the manufacturing supply chain, there are direct communication and interaction from the intangible product supplier or service provider to the final customer. 3) Usually, outputs cannot be stored, returned, or exchanged but can be renewed. In many cases, such works have a personalized, customized, or demand-specific 
feature.

Besides, products such as software can be customized to a company's requirements in any industry. Unlike other industry groups, the service or product quality depends on the highly skilled and trained workforce service quality. Therefore, expenses paid for highly skilled workforce services constitute a significant part of the total costs. Accordingly, financial ratios related to such costs will be more visible as explanatory variables in estimating FFP models.

\subsubsection{Estimation Coefficients and Models}

The broad variable groups chosen at the pre-processing stage for the Group III sector were filtered down to the most critical three explanatory variables using the stepwise regression procedure. As presented in Table 11, the regression coefficients $(\beta)$ of the logit models and odds' ratios were constructed for the three-year periods before the financial failure date.

Given the coefficients' signs and odds' values ratios, the hypothesis of whether the variables have a significant contribution to the model was examined:

H0: $\beta=0$ (The selected variables do not have a significant contribution to the model)

H1: $\beta \neq 0$ (The selected variables have a significant contribution to the model)

Considering the $p$-value (sig.) of four explanatory variables with less than $0.05 \%$ and the confidence level of $95 \%$, the H0: $\beta=0$ (null) hypothesis was rejected. Accordingly, all three explanatory variables contributed to the model, as indicated by their respective values of significance (odds ratios).

Compared with the data samples used in the two main industry groups (Group I and II), the data samples used in developing the model for Group III were small. For example, 2346 data samples were used for the manufacturing industry, 582 data samples for the Group II sector, whereas 274 data samples were used for the Group III sector during the development of variable selection and FFP models. Despite small data samples, Group III's available data were still above the minimum number required for logit regression calculation; thus, the developed models' outcome was reasonably significant.

The average coefficients' function of the parameters was estimated by using logit regression covering a three-year period, which is formulated as follows:

Table 11. Coefficients $(\beta)$ of the logit models and the associated odds ratios for the group-III sector.

\begin{tabular}{|c|c|c|c|c|c|c|c|c|}
\hline & \multicolumn{8}{|c|}{ Years Before the Financial Failure Date } \\
\hline & \multicolumn{2}{|c|}{ Average Values } & \multicolumn{2}{|c|}{ One Year } & \multicolumn{2}{|c|}{ Two Year } & \multicolumn{2}{|c|}{ Three Year } \\
\hline & $\beta$ & Odds Ratio & $\beta$ & Odds Ratio & $\beta$ & Odds Ratio & $\beta$ & Odds Ratio \\
\hline Fixed Assets to Equity (FAE) & 1.416 & 4.244 & 1.698 & 5.461 & 1.451 & 4.268 & 1.099 & 3.002 \\
\hline Return on Equity Before Tax (ROE) & -4.190 & 0.015 & -4.036 & 0.018 & -4.279 & 0.014 & -4.256 & 0.014 \\
\hline Capital Turnover (CT) & -0.053 & 0.949 & -0.061 & 0.941 & -0.062 & 0.940 & -0.035 & 0.965 \\
\hline Constant & -0.506 & 0.606 & -0.519 & 0.595 & -0.632 & 0.532 & -0.368 & 0.692 \\
\hline
\end{tabular}




$$
\ln \left(\frac{p}{1-p}\right)=-0.506+1.415 \mathrm{FAE}-4.190 \mathrm{ROE}-0.052 \mathrm{CT}
$$

These results confirmed that the overall model during the given period is significant. The sign of the coefficients shows the nature of the relationship between the odd values and FFP models. As indicated in the formula above, three parameters, FAE ratio, return on equity, and capital turnover (CT), was the most relevant explanatory variables for the FFP model.

Considering the odds values in Table 11, the FAE, one of the financial structure (borrowing) variables, positively increased the FFP with an average factor of 4.244 odds ratio. Other independent variables such as the return on equity and the CT had a decreasing effect on the FFP failure with an average factor of 0.015 and 0.949 odds' ratios.

Furthermore, it is observed that the prediction power of all three parameters one year prior to the failure is moderately greater than two and three years before the failure date, with a minor exception of the FAE. Therefore, one year before the financial failure date is the better FFP period, commensurate with this sector's theoretical fundamentals in credit risk management.

\subsubsection{Predictive Power of the Models}

The classification Table 12 indicates the predictive accuracy of the binary LR models. Randomly selected total sampling data are divided into two groups: a training group with $60 \%$ sampling for estimating the FFP and the test group with $40 \%$ sampling to validate the training group's FFP. The classification power of both models for the Group III sector companies over three years before the failure were estimated as follows:

The classification results between the failed and non-failed companies for the Group III sector are different from those of other industry groups due to the unbalanced distribution of company data over the three years. For example, the sampling data of non-failed companies comprised $91.4 \%$ of the trained model and $87.6 \%$ of the test model. Subsequently, successful companies' predictive

Table 12. Predictive power of trained and test models up-to three years before the group-III sector's financial failure date.

\begin{tabular}{cccccc}
\hline & & \multicolumn{4}{c}{ Years Before the Financial Failure Date } \\
\cline { 3 - 6 } & & Average & One Year & Two Years & Three Years \\
\cline { 3 - 6 } & & \multicolumn{4}{c}{ Correct Percentage } \\
\hline \multirow{3}{*}{ Trained Model } & Non-failed companies & 91.4 & 89.4 & 93.5 & 91.3 \\
& Failed companies & 50.7 & 50.8 & 46.8 & 54.5 \\
& Overall Percentage & $\mathbf{7 6 . 6}$ & $\mathbf{7 5 . 2}$ & $\mathbf{7 7 . 7}$ & $\mathbf{7 7}$ \\
\hline \multirow{3}{*}{ Test Model } & Non-failed companies & 87.6 & 87.3 & 83.6 & 92 \\
& Failed companies & 55.5 & 48.7 & 59.5 & 58.3 \\
& Overall Percentage & $\mathbf{7 6 . 2}$ & $\mathbf{7 3 . 6}$ & $\mathbf{7 3 . 9}$ & $\mathbf{8 1 . 1}$ \\
\hline
\end{tabular}


power in the trained and test models was significantly higher than failed companies over three-year periods.

Therefore, the classification power of non-failed companies was estimated to be very significant during one, two, and three years before the failure date at $89.4 \%, 93.5 \%$, and $91.3 \%$ in the trained model and $87.3 \%, 83.6 \%$, and $92 \%$ in the test model, respectively. Nevertheless, the predictive power for failed companies was more than $50 \%$ in both trained and test models due to comparatively lower sampling data used in binary regression analysis.

In conclusion, the average prediction powers covering the three-year periods were $76.6 \%$ for the trained model, which was validated equally by the test model's result of $76.2 \%$.

A similar result was observed with regard to the cost of Type I and Type II errors. Averages of types of errors for trained and test models' companies were calculated as $23.4 \%$ (100 - 76.6) and $23.8 \%$ (100 - 76.2), respectively. However, a higher percentage of Type II error with $49.3 \%$ is not preferred to the Type I error with $8.6 \%$ from the financiers' perspective. The risk of classifying the financially failed companies as successful may increase the cost of non-performing loans for the financial institution's portfolios.

\subsubsection{Variables Interpretation for the Group III Sector}

Although the independent variables were selected from different financial ratio groups such as borrowing, sales turnover, and profitability, they have the same denominator item, namely "owners' equity", which critically determines the Group III sector's FFP. The explanatory variables starting from the highest impact on financial failure risk are interpreted as follows:

Fixed assets to equity ratio (FAE): The FAE is formulated as the ratio of fixed assets to equity, which indicates how much of a company's fixed assets are acquired by the owners' equity versus long-term debt. In this case, fixed assets are long-term assets that refer to a company's long lifetime property, equipment, and plant. The FAE ratio precisely measures the comparative exposure of owners' equity versus the financiers of a company. Therefore, the more increase in the FAE ratio means more long-term debt financing for the fixed assets. Those companies are likely to be debt-ridden, usually running into solvency and liquidity issues. Therefore, the high FAE rate exposed Group III companies to a significant risk of the FFP with an average factor of 4.244 odds ratio over the three years.

Most of this sector group's workforce is required to be highly qualified, skilled, educated, and well-equipped with technology-intensive software tools and equipment in executing operations and services. Therefore, it is expected that there is less requirement for long-term assets when compared with other sectors. Thus, funding for such assets should preferably be provided from the shareholders' equity. Otherwise, as observed, the risk of FFP is significant. Kaygin et al. (2016) observed a similar result of selecting the FAE ratio as an explanatory variable for the FFP model in the study on Turkish companies. 
Capital Turnover (CT): CT is one of the sales turnover ratios formulated by dividing the net sales by the owners' equity. The $\mathrm{CT}$ is an important measure indicating how effectively the shareholders' equity is utilized to generate income based on the sales turnover.

A high CT ratio indicates that the enterprise efficiently utilizes its equity resources with high sales, stock, and receivable turnover rates. The low CT rate proves the opposite. The company cannot use its equity effectively, and the business operations are financed mainly through equity capital. Hence, the increase in the sales turnover causes increases in the stock and receivable turnovers, ultimately reducing financial failure.

Accordingly, this explanatory variable was found to be successful in predicting business failure at a significant effect level by reducing FFP to an average factor of 0.949 odds ratios. This result was very similar to the values estimated for one, two, and the three years before the failure with the highest factor of 0.941, 0.940, and 0.965 odds ratios, respectively.

Return on Equity Before Tax (ROE): The ROE is one of the profitability ratios that shows the relationship between its pre-tax profit and capital. It decreased the financial failure risk by an average factor of 0.015 percent over the given period. It was the third and least influential independent variable in the FFP Model for the Group III sector.

As explained previously, the ROE is selected as the independent variable for both models of Group II and III sectors in predicting the risk of the companies' financial failures with an average factor of 0.647 and 0.015 odds ratios, respectively.

\section{Conclusion}

This study aimed to develop and validate the FFP models utilizing financial ratios combined with several markets and macroeconomic variables for the Turkish manufacturing corporates, which traded on the BIST between 2007 and 2019. Early prediction of a company's financial failure with a reliable financial distress model is beneficial for various corporate stakeholders, especially in global financial and economic volatility.

Companies were divided into three groups based on sub-sectoral characteristics. Such sectors are Group I (Production and Manufacturing Industry Sectors), Group II (Trade, Transportation, and other Service Sectors), and Group III (IT Technology, Administrative, and Support Service Sectors).

After the factor analysis, forty-one explanatory variables, including market and macroeconomic variables were reduced to eighteen of the most significant independent variables at the end of the pre-processing step. Those variables were defined as "wide variables group," covering liquidity, leverage, and profitability ratios as the model predictions' critical financial factors. Further, macroeconomic and stock market variables such as non-performing loans-to-total loans ratio, loan interest rates, and the BII were critical factors, among the wide va- 
riables group, in the FFP model.

A stepwise regression procedure was applied in the next stage to refine the variables further and avoid multi-collinearity issues while systematically selecting the best ultimate predictors from the eighteen explanatory variables. Finally, binary LR analysis was deployed to construct the FFP models over one, two, and three years before the failure of each respective group of companies (Group I, II, and III) using their unique variables.

Overall empirical results of FFP models for each group of companies were significant at an alpha level of 0.05 . Moreover, the hypothesis was tested at a 95\% confidence level (confidence interval).

Regarding the Group-I sector, the relevant explanatory variables consist of ER, STL, and ROA. BII was found to be significant in FFP models three years before the financial failure date. BII was the only market variable making a meaningful contribution to the FFP models. Positive results were obtained when measuring the predictive power of both trained and test models with an average of $71.3 \%$ and $70.8 \%$, respectively, in classifying and predicting financial failures for this group sector.

The Group II sector's four parameters: GPM, ROA, return on equity, and DR helped the FFP model during the three-year period before the failure dates. Return on equity, which reduces the risk of financial failure significantly, was observed to be the same explanatory variable in Group I and II sectors. Similarly, positive results were obtained from both trained and test models with an average classification rate of $68.5 \%$ and $76.8 \%$, respectively, for the three years.

Concerning the Group III sector, three parameters, FAE ratio, return on equity, and CT, significantly contributed to the FFP model over the given period. Although the independent variables were selected from different financial ratio groups such as leverage, sales turnover, and profitability, they have the same denominator item, namely, "owners' equity", which critically determines the FFP for this sector. The average prediction powers covering the three periods are $76 \%$ for the trained model, validated by the test model's result of $76.2 \%$.

Except for two variables, nine independent variables representing the financial ratios were identified as the sector-specific parameters in the FFP models. Each group's trained models' classification power can achieve reasonable predictive success rates and be validated by the corresponding test models at 1,2 , and 3 years in advance. Furthermore, the binary logit regression model without binding the normal distribution assumptions is stronger and more successful than the discriminant method.

In summary, using LR methodology, the importance of leverage, profitability, and turnover of assets, and macroeconomic factors are significant in predicting financial failures 1 - 3 years before financial difficulties for Turkish companies. Thus, the FFP models with the most influential factors can be used by all stakeholders concerned to take early necessary precautions by implementing timely turnaround strategies to eliminate the risk of adverse effects of the companies operating in the different sectors. 
In this research, the results of the FFP models display a reasonably high classification accuracy and predictive power of three sets of variables (financial ratios, market, and macroeconomic variables) in a logit model for quoted companies in the developing country, Turkey.

Nevertheless, the following limitations need to be addressed for further research in this field: 1) The three sets of explanatory variables comprehensively combined in a single FFP model for each sub-sector group to measure overall performance. In addition to a single compressive model, the "staging approach" is worth exploring, starting with the "financial rations only" model. Then, adding a "financial rations plus market variables" to the model till reaching all-inclusive the three sets of explanatory variables. Consequently, a comparison of the classification accuracy and predictive power of three types of variables for each sub-sector group can be made.

2) The two types of outcomes based on "failed" or "not failed" classification were investigated throughout this study. Therefore, the binomial distribution is used in the FFP model. As a result of the recent global economic crisis, various measurements have been taken by the financial authorities for the corporates in the different stages, such as financial failures, distress, restructuring, and bankruptcy. Therefore, more polytomous models are needed for the FFP with more than two possible dependent variables (response variables) based on a polytomous response regression model, where the response possible outcomes reflect the different stages of financially distressed or failed companies.

3) In this study, the FFP models for each sub-sector group were developed based on statistical method, which is limited to logistic regression. In addition to the statistical method, machine learning techniques and artificial neural networks (ANN) need to be used for the comparison of the classification accuracy and predictive power of FFP models.

\section{Conflicts of Interest}

The authors declare no conflicts of interest regarding the publication of this paper.

\section{References}

Aksoy, B., \& Boztosun, D. (2018). Financial Failure Prediction Using Discriminant and Logistic Regression Methods: BIST Manufacturing Sector Example. Journal of Financial, Political and Economic Comments, 55, 9-32.

Aktaş, R. (1993). Financial Failure Prediction for Industrial Enterprises (Multidimensional Model Application). Türkiye İş Bankası Kültür Yayınları.

Aktaş, R., Doğanay, M., \& Yıldız, B. (2003). Financial Failure Prediction: Statistical Methods and Artificial Neural Network Comparison. Ankara Üniversitesi SBF Dergisi, 58, 1-24. https://doi.org/10.1501/SBFder_0000001632

Altman, E. I. (1968). The Prediction of Corporate Bankruptcy: A Discriminant Analysis. Journal of Finance, 23, 193-194. https://doi.org/10.2307/2325319

Altman, E. I., Haldeman, R. G., \& Narayanan, P. (1977). ZETA TM Analysis: A New 
Model to Identify Bankruptcy Risk of Corporations. Journal of Banking \& Finance, 1, 29-54. https://doi.org/10.1016/0378-4266(77)90017-6

Beaver, W. H. (1966). Financial Ratios as Predictors of Failure. Journal of Accounting Research, 4, 71-111. https://doi.org/10.2307/2490171

Blum, M. (1974). Failing Company Discriminant Analysis. Journal of Accounting Research, 12, 1-25. https://doi.org/10.2307/2490525

Chen, K. H., \& Shimerda, T. A. (1981). An Empirical Analysis of Useful Financial Ratios. Financial Management, 10, 51-60.

Christidis, A. C., \& Gregory, A. (2010). Some New Models for Financial Distress Prediction in the UK. Centre for Finance and Investment Discussion Paper No. 10/04.

Cramer, J. S. (2003). Some Statistical Tests and Measures of Fit. In Logit Models from Economics and Other Fields (pp. 56-72). Cambridge University Press. https://doi.org/10.1017/CBO9780511615412.005

Davis, E. P., \& Karim, D. (2008). Comparing Early Warning Systems for Banking Crises. Journal of Financial Stability, 4, 89-120. https://doi.org/10.1016/j.jfs.2007.12.004

Deakin, E. B. (1972). A Discriminant Analysis of Predictors of Business Failure. Journal of Accounting Research, 10, 167-179. https://doi.org/10.2307/2490225

Dwyer, M. M. D. (1992). A Comparison of Statistical Techniques and Artificial Neural Network Models in Corporate Bankruptcy Prediction (Bankruptcy). University of Wisconsin at Madison.

Elam, R. (1975). The Effect of Lease Data on the Predictive Ability of Financial Ratios. The Accounting Review, 50, 25-43.

Erkut, G. (1981). An Empirical Study on the Estimation of Financial Failure for Industrial Enterprises Using the Accounting Ratios and Discriminant Analysis Technique. Unpublished Associate Professor Thesis, National Thesis Center, The Council of Higher Education in Turkey.

Ertan, A. S., \& Ersan, Ö. (2018). Determinants of Financial Default: The Case of Manufacturing Industry in Turkey. Marmara Üniversitesi Íktisadi ve İdari Bilimler Dergisi, 40, 181-207.

Fitzpatrick, P. J. (1932). A Comparison of Ratios of Successful Industrial Enterprises with Those of Failed Firms. Certified Public Accountant, 12, 598-729.

Gujarati, D., \& Porter, D. (Eds.) (2009). Basic Eonometrics (5th ed., International ed.). McGraw-Hill.

Hall, S., \& Pellet, P. F. (2003). The Macroeconomic and Microeconomic Factors Influencing Financial Distress: A Comparison of Altman's 1983 and 1993 Bankruptcy Prediction Models. Dissertations and Theses, Nova Southeastern University, ProQuest.

Kaygin, Y. C., Tazegül, A., \& Yazarkan, H. (2016). Estimation Capability of Financial Failures and Successes of Enterprises Using Data Mining and Logistic Regression Analysis. Journal of Ege Academic Review, 16, 147-159.

Korol, T., \& Korodi, A. (2010). Predicting Bankruptcy with the Use of Macroeconomic Variables. Economic Computation and Economic Cybernetics Studies and Research/ Academy of Economic Studies, 44, 201-219.

Kwak, S. K., \& Kim, J. H. (2017). Statistical Data Preparation: Management of Missing Values and Outliers. Korean Journal of Anesthesiology, 70, 407-411. https://doi.org/10.4097/kjae.2017.70.4.407

Laitinen, T., \& Kankaanpaa, M. (1999). Comparative Analysis of Failure Prediction Methods: The Finnish Case. European Accounting Review, 8, 67-92. 
https://doi.org/10.1080/096381899336159

Libby, R. (1975). Accounting Ratios and the Prediction of Failure: Some Behavioral Evidence. Journal of Accounting Research, 13, 150-161. https://doi.org/10.2307/2490653

Liu, J. (2004). Macroeconomic Determinants of Corporate Failures: Evidence from the UK. Applied Economics, 36, 939-945. https://doi.org/10.1080/0003684042000233168

Merwin, C. L. (1942). Financing Small Corporations in Five Manufacturing Industries, 1926-1936, National Bureau of Economic Research, New York.

Nouri, B. A., \& Soltani, M. (2016). Designing a Bankruptcy Prediction Model Based on Account, Market and Macroeconomic Variables (Case Study: Cyprus Stock Exchange). Iranian Journal of Management Studies, 9, 125-147. https://doi.org/10.22059/ijms.2016.55038

Odom, M. D., \& Sharda, R. (1990). A Neural Network Model for Bankruptcy Prediction. 1990 IJCNN International Joint Conference on Neural Networks, San Diego, 17-21 June 1990, 163-168. https://doi.org/10.1109/IJCNN.1990.137710

Ohlson, J. A. (1980). Financial Ratios and the Probabilistic Prediction of Bankruptcy. Journal of Accounting Research, 18, 109-131. https://doi.org/10.2307/2490395

Pham Vo Ninh, B., Do Thanh, T., \& Vo Hong, D. (2018). Financial Distress and Bankruptcy Prediction: An Appropriate Model for Listed Firms in Vietnam. Economic Systems, 42, 616-624. https://doi.org/10.1016/j.ecosys.2018.05.002

Polat, H. (2011). Intra-Industry Trade of Manufacturing Industry in Turkey: 1980-2007. Dicle University Journal of Economics and Administrative Sciences, 1, 127-146. https://dergipark.org.tr/en/pub/duiibfd/issue/32247/357881

Ramser, J. R., \& Foster, L. O. (1931). A Demonstration of Ratio Analysis. Bulletin No. 40. Bureau of Business Research, University of Illinois, Urbana.

Sanche, R., \& Lonergan, K. (2006). Variable Reduction for Predictive Modeling with Clustering. Casualty Actuarial Society Forum, pp. 89-100.

Sayılgan, G., \& Coşkun, E. (2007). Using Sector-Adjusted Ratios in Estimating Financial Failure. Zonguldak Karaelmas Üniversitesi, IIBF, İşletme Bölümü, 11. Ulusal Finans Sempozyumu Bildiriler Kitab1, 17-20 Ekim, Zonguldak 111-129.

Scott, J. (1981). The Probability of Bankruptcy. A Comparison of Empirical Predictions and Theoretical Models. Journal of Banking \& Finance, 5, 317-344. https://doi.org/10.1016/0378-4266(81)90029-7

Shi, Y., \& Li, X. (2019). An Overview of Bankruptcy Prediction Models for Corporate Firms: A Systematic Literature Review. Intangible Capital, 15, 114-127. https://doi.org/10.3926/ic.1354

Smith, R. F., \& Winakor, A. H. (1935). Changes in the Financial Structure of Unsuccessful Industrial Corporations. Urbana: University of Illinois.

Stenbäck, T. (2013). Corporate Default Prediction with Financial Ratios and Macroeconomic Variables. Economics Master's Thesis, Aalto University School of Business, Department of Economics. https://aaltodoc.aalto.fi/bitstream/handle/123456789/11760/hse_ethesis_13393.pdf

Sun, J., Li, H., Huang, Q., \& He, K. (2014). Predicting Financial Distress and Corporate Failure: A Review from the State-of-the-Art Definitions, Modeling, Sampling, and Featuring Approaches. Knowledge-Based Systems, 57, 41-56. https://doi.org/10.1016/j.knosys.2013.12.006

Taffler, R. J. (1983). The Assessment of Company Solvency and Performance Using a Statistical Model. Accounting and Business Research, 13, 295-308.

https://doi.org/10.1080/00014788.1983.9729767 
Tinoco, H. M., \& Wilson, N. (2013). Financial Distress and Bankruptcy Prediction among Listed Companies Using Accounting, Market and Macroeconomic Variables. International Review of Financial Analysis, 30, 394-419.

https://doi.org/10.1016/j.irfa.2013.02.013

Uğurlu, M., \& Aksoy, H. (2006). Prediction of Corporate Financial Distress in an Emerging Market: The Case of Turkey. Cross Cultural Management, 13, 277-295. https://doi.org/10.1108/13527600610713396

Ural, K., Gürarda, Ş., \& Önemli, B. M. (2015). Financial Failure Estimation with Logistic Regression Model: Application in Food, Beverage and Tobacco Companies Listed on Borsa Istanbul. Journal of Accounting and Finance (Muhasebe ve Finansman Dergisi), No. 67, 85-100. https://doi.org/10.25095/mufad.396578

Zmijewski, M. E. (1984). Methodological Issues Related to the Estimation of Financial Distress Prediction Models. Journal of Accounting Research, 22, 59-82.

https://doi.org/10.2307/2490859 